\title{
EFFECTS OF MANURE BEDDING ON THE RATE OF CLAW DISEASES IN DAIRY COWS
}

\author{
Mudroň, $P$. \\ Clinic for Ruminants \\ University of Veterinary Medicine and Pharmacy \\ Komenskeho 73, 04181 Košice \\ The Slovak Republic \\ pavol.mudron@uvlf.sk
}

\section{ABSTRACT}

This study was conducted to determine the prevalence of claw diseases in dairy cows housed on two different bedding systems: deep straw bedding and unsterilized recycled manure solids. On the farm (farm A) with the straw bedding, 403 and on the farm (farm B) with manure solid bedding, 226 dairy cows were examined. The prevalence of cows with one or more claw lesions on the farm with straw bedding and with manure solids were $37 \%$ and $69 \%$, respectively $(\mathrm{P}<0.001)$. In both bedding systems, two claw lesions dominated: digital dermatitis and inflammatory disorders of corium (white line diseases, toe ulcer, and sole ulcer). The prevalence of the digital dermatitis housed in deep-bedded freestalls and in freestalls with manure solids were $17.8 \%$ and $53.1 \%(P<0.001)$, respectively. The prevalence of the white line diseases and toe ulcer were $12.1 \%$ and $15.7 \%$ on farm $A$ and $3.88 \%$ and $2.59 \%$ on farm $B$, respectively $(P<0.001)$. There was no significant difference in the prevalence of the sole ulcer between farms. These data indicate a relatively high prevalence of claw lesions on the studied dairy farms. Moreover, a long-term contact of claws with manure (boxes and corridors) on the farm with unsterilized recycled manure solids seems to be associated with a higher prevalence of digital dermatitis.

Key words: claw diseases; dairy cows; lameness; manure bedding

\section{INTRODUCTION}

Claw diseases, especially injuries and infections of the feet, constitute one of the most serious and painful, yet least well-managed categories of diseases for the modern high yielding dairy cow. This problem has been recognised and studied for many years, but is not getting any better. Approximately $70 \%$ of intensively managed dairy cattle in North America were affected by claw diseases [6], and the recently reported lameness prevalence in the U. K. dairy herds ranged from $0-80 \%$ [1].

A high proportion of cows becomes lame within the first two months of their first lactation and regularly re- 
lapse. This indicates quite clearly that conventional, accepted practices for housing, feeding and managing of the modern Holstein-Friesian dairy cow lead to injury or otherwise affect the feet to a degree where $50 \%$ of the animals will experience the chronic pain of lameness in any one lactation [30].

The obvious consequences of lameness are: less time spent eating, less movement to bunks, subsequent weight and production losses, and failure to show heat. Extreme lameness with weight loss causes a negative energy balance and can cause anoestrus [16]. Assessing the effect of such diseases on milk yield is a difficult task [10]. Milk production before disease incidence can confound the effect of such disease on overall milk yields. Milk yield was higher before than after a lameness occurrence; high milk production was associated with lameness [13]. Lameness prevention remains a significant priority for the dairy industry as consumer demand drives changes in housing and management to promote improved wellbeing, and farmers strive to improve productivity. Providing a clean, dry, and comfortable surface for cows to rest on is important for the welfare of dairy cows, as they spend approximately $12 \mathrm{~h}$ per day resting [15]. The lameness prevalence appears to be greater in freestall facilities compared with other management systems such as tie-stall housing $[3,23]$. Leg lesions were observed less frequently in cows housed in deep-bedded sand stalls than cows on mattresses [11] and severe lesions were less prevalent in sand beds than on mattresses [28]. The exposure to concrete walking surfaces in alleys and other changes such as the regrouping of cattle around the time of calving are potential differences typical of freestall design and management that may be important factors elevating lameness risk [5]. Increased costs and reduced availability of other common bedding sources has prompted many dairy producers to search for more feasible alternatives such as sand or recycled manure solids. Although sand can be considered the ideal bedding source for dairy cows, not all producers are willing and able to convert to sand bedding, as it presents several challenges related to manure management [17].

The aim of this study was to compare the prevalence of claw diseases in dairy cows housed on two different bedding systems: straw bedding and recycled manure solids.

\section{MATERIALS AND METHODS}

This study was conducted on two dairy farms. All the animals were housed in a free stall system. On the farm with the deep straw bedding (Farm A), 403 and on the farm with manure solid bedding (Farm B), 226 Holstein-Frisian dairy cows were examined. The dairy cows on the farm A with deep straw bedding (group size of 60 cows per pen, approximately) had lying areas with $80 \mathrm{~cm}$ of straw available. The farm B with manure solids was equipped with cubicles with concrete basement floor. Recycled manure solids were obtained from the mechanical separation of raw manure and used for cubicle bedding without any chemical and thermal processing. The depth of this bedding varied from $20-30 \mathrm{~cm}$.

The average yearly milk yield on the Farm A and B was 7,400 and $8,200 \mathrm{~kg}$, respectively. The dairy cows were fed by total mixed ration (TMR) on both farms with maize and alfalfa silage as the main components. Claw trimming was performed twice a year by external professional claw trimmers. No claw bathing was performed on either farms.

All the dairy cows were examined and treated in the trimming crush for claw lesions by one person. The clinical examination was focused on the following claw lesions [29]: digital dermatitis, heal horn erosions, white line diseases, toe ulcer, sole ulcer (pododermatitis circumscripta specifica), interdigital fibroma, sole haemorrhage, and chronic laminitis (horizontal horn fissures and concave wall). The cases of digital dermatitis were recorded for each leg and other lesions for each claw (eight claws per cow).

The statistical analysis was performed by running a chisquared test using the statistical software StatSoft, version 8.0. P-values $\leq 0.05$ were considered significant.

\section{RESULTS}

The prevalence of cows with one or more claw lesions on the farm with straw bedding (A) and with manure solids (B) were $37 \%$ and $69 \%$, respectively $(\mathrm{P}<0.001)$. The dairy cows of farm B had more than one lesion per head, demonstrating a higher prevalence of claw diseases in the herd with manure solids (Table 1).

The results from the chi-squared test describing individual claw lesions on deep straw bedding versus manure solids are shown in Table 2. 
Table 1. Prevalence of claw lesions in dairy cows on different beddings

\begin{tabular}{lccccc}
\hline \multicolumn{1}{c}{ Variable } & $\begin{array}{c}\text { Number } \\
\text { of dairy cows }\end{array}$ & $\begin{array}{c}\text { Cows with } \\
\text { lesions }\end{array}$ & $\begin{array}{c}\text { Lesion } \\
\text { count }\end{array}$ & $\begin{array}{c}\text { Lesion count } \\
\text { per cow }\end{array}$ & $\begin{array}{c}\text { Lesion count per cow } \\
\text { with lesions }\end{array}$ \\
\hline Deep straw bedding & 403 & $151(37 \%)^{\mathrm{a}}$ & 223 & 0.55 & 1.48 \\
Manure solids & 226 & $156(69 \%)$ & 309 & 1.37 & 1.98 \\
\hline
\end{tabular}

$\mathrm{a}-\mathrm{P}<0.001$

Table 2. Prevalence of individual claw diseases in dairy cows on different beddings

\begin{tabular}{lcc}
\hline \multicolumn{1}{c}{ Variable } & Deep straw bedding & Manure solids \\
\hline Number of dairy cows & 403 & 226 \\
Lesion count (100\%) & 223 & 309 \\
Digital dermatitis & $17.5 \%$ & $53.1 \% \mathrm{a}$ \\
Heel erosion & $21.5 \%$ & $18.8 \%$ \\
White line diseases & $12.1 \%$ & $3.88 \% \mathrm{a}$ \\
Toe ulcer & $15.7 \%$ & $2.59 \% \mathrm{a}$ \\
Sole ulcer & $9.43 \%$ & $3.23 \%$ \\
Interdigital fibroma & $17.9 \%$ & $12.3 \%$ \\
Sole haemorrhage & $3.59 \%$ & $5.83 \%$ \\
Chronic laminitis & $2.24 \%$ & $0.32 \%$ \\
\hline
\end{tabular}

$\mathrm{a}-\mathrm{P}<0.001$

In both bedding systems, two types of claw lesions dominated: digital dermatitis and inflammatory disorders of the corium (white line diseases, toe ulcer, and sole ulcer). The prevalence of the contagious digital dermatitis on farm $\mathrm{A}$ and $\mathrm{B}$ were $17.8 \%$ and $53.1 \%(\mathrm{P}<0.001)$, respectively. The prevalence of the white line diseases and toe ulcer was $12.1 \%$ and $15.7 \%$ on farm $A$ and $3.88 \%$ and $2.59 \%$ on farm $\mathrm{B}$, respectively $(\mathrm{P}<0.001)$. There was no significant difference in the prevalence of the sole ulcer between the farms.

No acute laminitis could be observed in the examined dairy cows. In addition, several cases of sole haemorrhage and chronic laminitis were found on both farms (Table 2).

\section{DISCUSSION}

Bovine lameness can be based from $85 \%$ on claw lesions associated with painful inflammatory processes. The remaining $15 \%$ of lameness cases are due to other locomotory disorders, including: diseases of joints, tendons, tendon sheets, muscles, and bones or animals suffering from neurological disorders [29].

Cows housed in the deep straw-bedded freestalls ( $\mathrm{n}$ $=403$ ) had a lower prevalence of claw lesions (37\%) than cows housed in the freestalls with manure solids (69\%; $\mathrm{n}=226$ ). This difference was based on a high occurrence 
of digital dermatitis on the farm with manure solids. Digital dermatitis represents a lesion that is frequently affecting more than one leg. However, some forms of digital dermatitis like M3 and M4 $[8,24]$ are not associated with painful conditions. Digital dermatitis prevalence was clearly on the farm with manure solids in the present study. We can speculate that the mixture of straw and faeces can represent in the case of deep straw bedding, a lower risk of skin infection with causative agents. Bovine digital dermatitis is a common, worldwide, painful, infectious disease of the feet of intensively managed cattle [21]. The cause of digital dermatitis is multifactorial with an essential spirochaetal bacterial component. Several cultural, phenotypic and molecular studies have demonstrated that the spirochetes belong to a diverse phylogenetic group of Treponema spp. [20]. Acute digital dermatitis lesions were reproduced experimentally in Holstein heifers, thus, a systematic method to determine the efficacy of interventions aimed at the control of acute digital dermatitis is now available [12]. A new hypothesis about the participation of Dichelobacter nodosus in the development of skin lesions typical for digital dermatitis has been demonstrated recently [22]. The authors hypothesise that external noxious stimuli allow D. nodosus to break down the epidermal barrier creating a suitable environment for the secondary invaders, Treponema species, which gradually take over the infection site. In agreement with the prevalence of the claw diseases in our study, a recent observation has revealed that the two most frequent claw diseases in dairy cows were digital dermatitis and septic corium inflammation [19].

Significant effects of stall surface on lameness prevalence have been reported $[4,9]$. In both studies, the lameness prevalence was compared between herds with deep-bedded sand and mattress-based freestalls. A lower lameness prevalence could be observed in the sand stalls in comparison with the non-sand ones [4]. Similarly, high producing Holstein cows had a lameness prevalence of $17.1 \%$ in herds with sand-based freestalls compared with $27.9 \%$ in herds with mattresses [9]. It is interesting to note that the claw lesion prevalence for deep straw beds in the current study was much lower than the lesion prevalence observed with manure solids bedding. Differences in lameness prevalence likely occur between deep-bedded and mattress based stalls due to greater resting comfort in deep-bedded stalls. When provided the choice between deep beds with either sand or sawdust bedding and mattresses with 2 to $3 \mathrm{~kg}$ of bedding, cows showed a preference for deep beds [27]. Several studies have shown cows prefer stalls with greater surface cushion and spend more time lying down and less time standing when stall surfaces provide a greater degree of comfort $[15,26]$. The use of mattresses as a stall surface has been implicated as a risk factor for lameness in dairy cows [7]. Deep-bedded freestalls likely provide greater comfort than mattresses with small amounts of bedding.

The higher prevalence of the white line diseases and toe ulcers in dairy cows on the farm A with deep straw bedding might be related to the impropriate walking surfaces of farm alleys. Risk factors for increased lameness were: the presence of damaged concrete in yards, cows pushing each other or turning sharply near the parlour entrance or exit, cattle grazing a pasture that is also grazed by sheep, the use of automatic scrapers, and delayed treatment of lame cows [2].

There are several preventive measures against high lameness prevalence, including: feeding, welfare, hoof trimming, and foot baths. Studies have shown that long intervals between hoof trimmings, or a lack of routine hoof trimming, is associated with an increased lameness [18, 25]. Professional trimming was found to be more effective on farms with no nutritional disorders and where refurbishment works were carried out. The greatest decrease in the prevalence of claw lesions was observed on farms which provided: professional trimming, effective footbathing, improved walking and resting surfaces, and which treated severely lame cows between regular trimmings [14]. However, claw trimming remains the most effective method available to facilitate producers to prevent claw disorders from evolving from the subclinical to the clinical stage.

These data of the present study indicate a relatively high prevalence of claw lesions on the studied dairy farms. In addition, a long-term contact of claws with manure (boxes and corridors) on the farm with unsterilized recycled manure solids seems to be associated with a higher prevalence of digital dermatitis. Generally, there was no overall effect of the manure solids on claw diseases rate in dairy cows.

\section{ACKNOWLEDGEMENT}

This study was supported by the Slovak Research and Development Agency under the contract No. APVV-0701-11. 


\section{REFERENCES}

1. Archer, S., Bell, N., Huxley, J., 2010: Lameness in UK dairy cows: a review of the current status. In Practice, 32, 492-504.

2. Barker, Z. E., Leach, K. A., Whay, H. R., Bell, N. J., Main, D.C. J., 2010: Assessment of lameness prevalence and associated risk factors in dairy herds in England and Wales. J. Dairy Sci., 93, 932-941.

3. Bergsten, C., Herlin, A.H., 1996: Sole haemorrhages and heel horn erosion in dairy cows: The influence of housing system on their prevalence and severity. Acta Vet. Scand., 37, 395-408.

4. Cook, N.B., 2003: Prevalence of lameness among dairy cattle in Wisconsin as a function of housing type and stall surface. J. Am. Vet. Med. Assoc., 223, 1324-1328.

5. Cook, N. B., Nordlund, K. V., 2009: The influence of the environment on dairy behaviour, claw health and herd lameness dynamics. Vet. J., 179, 360-369.

6. Defrain, J.M., Socha, M.T., Tomlinsonet, D. J., 2013: Analysis of foot health records from 17 confinement dairies. J. Dairy Sci., 96, 7329-7339.

7. Dippel, S., Dolezal, M., Brenninkmeyer, C., Brinkmann, J., March, S., Knierim, U., Winckler, C., 2009: Risk factors for lameness in freestall-housed dairy cows across two breeds, farming systems, and countries. J. Dairy Sci., 92, 5476-5486.

8. Dopfer, D., Koopmans, A., Meijer, F.A., Szakall, I., Schukken, Y.H., Klee, W., et al., 1997: Histological and bacteriological evaluation of digital dermatitis in cattle, with special reference to spirochaetes and Campylobacter faecalis. Vet. Rec., $140,620-623$.

9. Espejo, L. A., Endres, M. I., Salfer, J. A., 2006: Prevalence of lameness in high-producing Holstein cows housed in freestall barns in Minnesota. J. Dairy Sci., 82, 3052-3058.

10. Ettema, J.F., Capion, N., Hill, A.E., 2007: The association of hoof lesions at claw trimming with test-day milk yield in Danish Holsteins. Prev. Vet. Med., 79, 224-243.

11. Fulwider, W. K., Grandin, T., Garrick, D. J., Engle, T. E., Lamm, W.D., Dalsted, N.L., Rollin, B.E., 2007: Influence of free-stall base on tarsal joint lesions and hygiene in dairy cows. J. Dairy Sci., 90, 3559-3566.

12. Gomez, A., Cook, N.B., Bernardoni, N. D., Rieman, J., Dusick, A. F., Hartshorn, R., et al., 2012: An experimental infection model to induce digital dermatitis infection in cattle. J. Dairy Sci., 95, 1821-1830.

13. Green, L.E., Hedges, V.J., Schukken, Y.H., Blowey, R. W., Packington, A. J., 2002: The impact of clinical lameness on milk yield of dairy cows. J. Dairy Sci., 85, 2250-2256.
14. Gudaj, R., Brydl, E., Lehoczky, J., Komlosi, I., 2013: Different management methods on prevalence of lameness in 25 Holstein-Friesian herds in Hungary. Acta Vet. (Beograd), 63, 405-420.

15. Haley, D. B., de Passille, A. M., Rushen, J., 2001: Assessing cow comfort: Effects of two floor types and two tie stall designs on the behaviour of lactating dairy cows. Appl. Anim. Behav. Sci., 71, 105-117.

16. Hillman, R., Gilbert, R. O., 2008: Reproductive diseases. In Divers, T. J., Peek, S. F. (Eds): Rebhun's Diseses of Dairy Cattle. Elsevier Inc., 438-439.

17. Husfeldt, A.W., Endres, M.I., 2012: Association between stall surface and some animal welfare measurements in freestall dairy herds using recycled manure solids for bedding. J. Dairy Sci., 95, 5626-5634.

18. Manske, T., Hultgren, J., Bergsten, C., 2002: The effect of claw trimming on the hoof health of Swedish dairy cattle. Prev. Vet. Med., 54, 113-129.

19. Milosavljevic, P., Savic-Stevanovic, V., 2013: Frequency of some acropodium diseases in dairy cows in Serbia. Acta Vet. (Beograd), 63, 247-254.

20. Nordhoff, M., Moter, A., Schrank, K., Wieler, L.H., 2008: High prevalence of treponemes in bovine digital dermatitis - A molecular epidemiology. Vet. Microb., 131, 293-300.

21. Olechnowicz, J., Jaskowski, J. M., Antosik, P., Bukowska, D., Urbaniak, B., 2010: Claw diseases and lameness in Polish Holstein-Friesian dairy cows. Bull. Vet. Inst. Pulawy, 54, 93-99.

22. Rasmussen, M., Capion, N., Klitgaard, K., Rogdo, T., Fjeldaas, T., Boye, M., Jensen, T. K., 2012: Bovine digital dermatitis: Possible pathogenic consortium consisting of Dichelobacter nodosus and multiple Treponema species. Vet. Microb., 160, $151-161$.

23. Sogstad, A. M., Fjeldaas, T., Osteras, O., Plym Forshell, K., 2005: Prevalence of claw lesions in Norwegian dairy cattle housed in tie stalls and free stalls. Prev. Vet. Med., 70, 191-209.

24. Somers, J. G. C. J., Frankena, K., Noordhuizen-Stassen, E. N., Metz, J.H.M., 2003: Prevalence of claw disorders in Dutch dairy cows exposed to several floor systems. J. Dairy Sci., 86, 2082-2093.

25. Somers, J. G. C. J., Frankena, K., Noordhuizen-Stassen, E.N., Metz, J.H.M., 2005: Risk factors for interdigital dermatitis and heel erosion in dairy cows kept in cubicle housing in the Netherlands. Prev. Vet. Med., 71, 23-34.

26. Tucker, C. B., Weary, D.M., 2004: Bedding on geotextile mattresses: How much is needed to improve cow comfort? J. Dairy Sci., 87, 2889-2895. 
27. Tucker, C. B., Weary, D. M., Fraser, D., 2003: Effect of three types of free-stall surfaces on preferences and stall usage by dairy cows. J. Dairy Sci., 86, 521-529.

28. Weary, D.M., Taszkun, I., 2000: Hock lesions and freestall design. J. Dairy Sci., 83, 697-702.

29. Weaver, A. D. 2000: Lameness. In Andrews, A. H. (Ed): The Health of Dairy Cattle. Blackwell Science Ltd., 149-202.
30. Webster, J., 2002: Effect of environment and management on the development of claw and leg diseases. In Kaske, M., Scholz, H., Holtershinken, M. (Eds): Recent Development and Perspectives in Bovine Medicine. Hildesheimer Druck- und Verlags-GmbH, 248-256.

Received July 15, 2016

Accepted October 17, 2016 